\title{
Ectopic lingual thyroid: an entity not to be missed!
}

\begin{abstract}
Lingual thyroid results due to aberrant migration during embryological development of thyroid gland. Usually asymptomatic, but can present as dysphagia, respiratory obstruction, dysphonia, foreign body sensation. ${ }^{1}$ Here we present a case of an 18 year old male who presented with chief complaints of cough and foreign body sensation for last one month.
\end{abstract}

Keywords: thyroid, hypothyroidism, asymptomatic, ultrasound neck
Volume 4 Issue 4 - 2019

Darwin Kaushal, Neha Shakrawal, Amit Goyal, Nithin Prakasan Nair, Aman Kumar Verma, Dipika Prakash

Department of ENT, Head \& Neck Surgery, All India Institute of Medical Sciences, India

Correspondence: Neha Shakrawal, Department of ENT and Head\&Neck Surgery, All India Institute of Medical Sciences, Jodhpur-34200I, India, Tel +91-6375526223,

Email drnehasnmc2gmail.com

Received: July 02, 2019 | Published: August 07, 2019

\section{Introduction}

Thyroid gland develops from endodermal tissue of foramen cecum at anterior $2 / 3^{\text {rd }}$ and posterior $1 / 3^{\text {rd }}$ of tongue between $3^{\text {rd }}-4^{\text {th }}$ week of gestation, penetrate downward to reach its normal adult location at $2^{\text {nd }}-$ $4^{\text {th }}$ tracheal rings in the neck during $7^{\text {th }}$ week of gestation. ${ }^{1,2}$ Ectopic lingual thyroid is a rare congenital entity with prevalence of 1 in 1-3 lakh population. ${ }^{3}$ It occurs due to arrest of migration of endodermal tissue from foramen caecum to its final pre-laryngeal location in the beginning of its development. Aberrant migration can lead to presence of ectopic thyroid tissue at any of the locations in its natural course. Many a times there is no migration of thyroid tissue from foramen cecum resulting in lingual thyroid. Ectopic thyroid tissue can be found at any location in its normal migratory pathway, however has also been found in mediastinum, esophagus, adrenal gland and heart. ${ }^{4-7}$ Most common (90\%) form of ectopic thyroid is lingual thyroid. ${ }^{3}$ In such cases there is no thyroid tissue in the body elsewhere, therefore surgical excision must be avoided as this is the only functioning thyroid tissue left in the body.

\section{Case report}

We present a case of a 18 years old male who presented to our outpatient clinic with chief complaints of persistent cough and foreign body sensation since one month. He was completely asymptomatic before that. There was no history of weight loss, prolonged fever, sputum production and sore throat. There was no history suggestive of hypothyroidism. On examination, there was a small soft cystic midline swelling of size $4 \times 3 \mathrm{~cm}$ at the base of tongue extending to left lateral side (Figure 1). It was not bleeding on touch. Neck examination revealed absence of thyroid gland on palpation. There were no palpable neck nodes. Indirect laryngoscopy showed bilateral vocal cord mobility with normal endolarynx. Ultrasound neck showed absence of thyroid gland in normal anatomical location. Thyroid function test revealed T3- $1.31 \mathrm{ng} / \mathrm{ml}$, T4-8.7ug/dl, TSH-24.18uiu/ $\mathrm{ml}$. After getting endocrinology opinion, patient was started on 50 microgram of L-thyroxine. Further evaluation in the form of contrast enhanced computed tomography scan neck revealed cystic swelling of $3 \times 2 \mathrm{~cm}$ size with peripheral rim of enhancement suggestive of thyroid tissue at the base of tongue and absence of thyroid gland in normal anatomical location (Figure 2). Technetium 99m scan suggested increased isotope uptake at base of tongue and no uptake at the normal thyroid location.

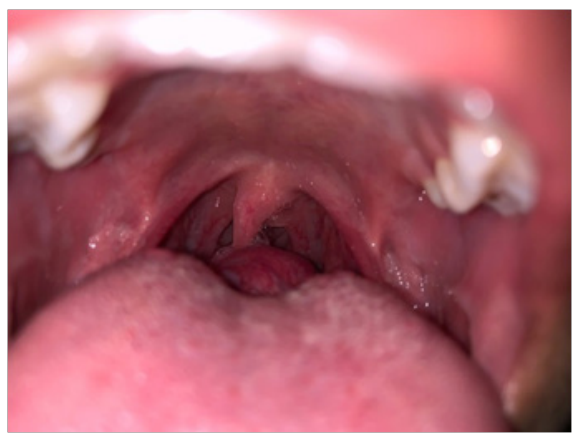

Figure I Oropharyngeal examination showing lingual thyroid.

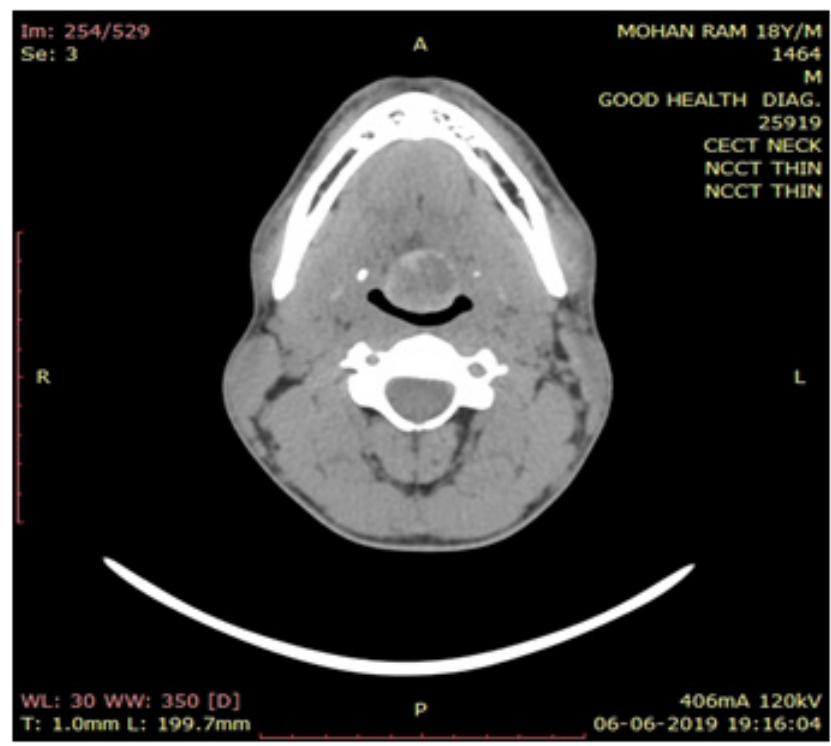




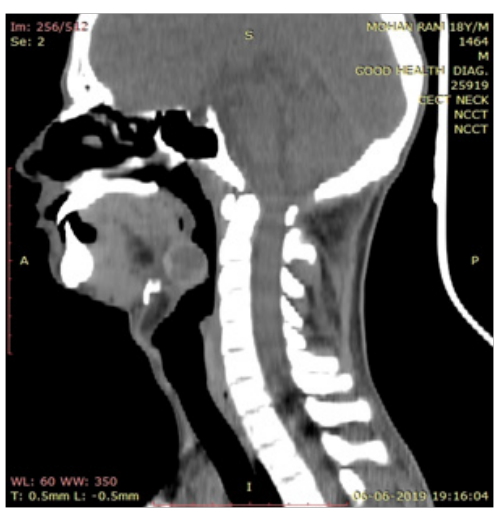

Figure 2 CECT scan showing a well-defined cystic swelling (indicated by arrow) of $3 \times 2 \mathrm{~cm}$ size with peripheral rim of enhancement at base of tongue. (Axial and Sagittal view).

\section{Discussion}

Ectopic thyroid is a rare aberration during the descent of normal thyroid tissue. The sites for ectopic thyroid tissue can be lingual, sublingual, pretracheal, prelaryngeal and substernal. There are chances that normal thyroid tissue is also present along with ectopic thyroid tissue. ${ }^{8-10}$ In 1869 , Hickman is credited for first lingual thyroid and Montgomery is credited for defining ectopic thyroid after the presence of follicles in the histopathology. ${ }^{11}$

True incidence cannot be calculated as majority of the patients are asymptomatic. Most common clinical presentations are mainly obstructive types such as airway obstruction, dysphagia, and difficulty in speech. ${ }^{12}$ Our patient's main complaint was persistent cough and foreign body sensation which he was ignoring since the beginning.

One third of the total patients present with hypothyroidism. ${ }^{12}$ Rarely patient can present with hyperthyroidism and suspicion of malignancy should also be kept in mind. ${ }^{13}$ Thorough clinical work up is required to look for the only thyroid tissue in the body. Proper clinical examination and Technetium 99m thyroid scan plays an utmost role in identifying any functional thyroid tissue in the body. The other prerequisites are thyroid profile, ultrasound neck, computed tomographic scan and contrast enhanced magnetic resonance imaging.

In $70 \%$ of the patients, normal thyroid gland is not present and the only functional thyroid is the ectopic thyroid. ${ }^{14}$ In our case also there was no normal thyroid gland.

The differentials which should be considered are teratomas, vallecular cysts, granulomas, neoplasms..$^{15}$ They can also present as adenoma, inflammation, hyperplasia or neoplasm. Marsupialization of vallecular cysts should not be done without proper investigations, as it can harm the patient rather than treating the cause.

Asymptomatic patients should be kept on close follow up and should be started on suppressive therapy to reduce the size of ectopic thyroid tissue. In our patient we started 50 microgram levothyroxine suppressive therapy to reduce the size of the ectopic thyroid tissue. The symptoms which warrant surgery are severe respiratory distress, dysphagia, dysphonia, uncontrolled hyperthyroidism or haemorrhage. ${ }^{16}$

\section{Conclusion}

Lingual swelling in children and young adults should be investigated with suspicion of thyroid tissue remnant/ thyroglossal cyst in mind. Before embarking upon surgical intervention, thorough check up in the form of at least thyroid profile, ultrasound neck, thyroid scan must be done as these swellings may be the only functioning thyroid tissue present in the body.

\section{Funding}

None.

\section{Acknowledgments}

None.

\section{Conflicts of interest}

The author declares there is no conflicts of interest.

\section{References}

1. Toso A, Colombani F, Averono G, et al. Lingual thyroid causing dysphagia and dyspnoea. Case reports and review of the literature. Acta otorhinolaryngol Ital. 2009;29(4):213-217.

2. Johansson E, Andersson L, Ornros J, et al. Revising the embryonic origin of thyroid C cells in mice and humans. Development. 2015;142(20):35193528 .

3. Nasiru Akamnu I, Idowu Olusegun F. Ectopic thyroid: etiology, pathology and management. Hormones. 2011;10(4):261-269.

4. Arriaga MA, Myers EN. Ectopic Thyroid in the Retroesophageal Superior Mediastinum. Otolaryngol Neck Surg. 1988;99(3):338-340.

5. Postlethwait RW, Detmer DE. Ectopic Thyroid Nodule in the Esophagus. Ann Thorac Surg. 1975;19(1):98-100.

6. Bozkirli E, Bakiner O, Belli S, et al. Ectopic thyroid tissue in the adrenal gland: report of a case. Endocr Abstr. 2015;37:76.

7. Casanova JB, Daly RC, Tazelaar HD. Intracardiac Ectopic Thyroid. Ann Thorac Surg. 2000;70(5):1694-1696.

8. Ulug T, Ulubil SA, Alagol F. Dual ectopic thyroid: report of a case. $J$ Laryngol Otol. 2003;117(7):574-576.

9. Hazarika P, Siddiqui SA, Pujary K, et al. Dual ectopic thyroid: a report of two cases. J Laryngol Otol. 1998;112(4):393-395.

10. Huang TS, Chen HY. Dual thyroid ectopia with a normally located pretracheal thyroid gland: case report and literature review. Head Neck. 2007;29(9):885-888.

11. Burkart CM, Brinkman JA, Willging JP, et al. Lingual cyst lined by squamous epithelium. Int J Pediatr Otorhinolaryngol. 2005;69(12):16491653.

12. Williams JD, Sclafani AP, Slupchinskij O, et al. Evaluation and management of the lingual thyroid gland. Ann Otol Rhinol Laryngol. 1996;105(4):312-316.

13. Abdallah Matta MP, Dubarry PH, Pessey JJ, et al. Lingual thyroid and hyperthyroidism: A new case and review of the literature. J Endocrinol Invest. 2002;25(3):264-267.

14. Babademez MA, Gunbey E, Acar B, et al. A rare cause of obstructive sleep apnea syndrome: Lingual thyroid. Sleep Breath. 2012;16(2):305308.

15. Koch CA, Picken C, Clement SC, et al. Ectopic lingual thyroid: An otolaryngologic emergency beyond childhood. Thyroid. 2000;10(6):511514.

16. Kumar SS, Kumar DM, Thirunavukuarasu R. Lingual thyroidconservative management or surgery? A case report. Indian J Surg. 2013;75(Suppl 1):118-119. 